\title{
Benzoylacetone as a Building Block in Heterocyclic Synthesis: Synthesis of Polyfunctionally Substituted Pyridinethione and Its Derivatives
}

\author{
Abdel Haleem Mostafa Hussein*, Fathi Ali Abu-Shanab, Sayed Abdel Hamed Sayed Mousa \\ Department of Chemistry, Faculty of Science, Al Azhar University, Assiut, Egypt \\ Email: ${ }^{*}$ abdelhaleemmh@yahoo.com
}

Received 5 January 2015; accepted 22 January 2015; published 26 January 2015

Copyright (C) 2015 by authors and OALib.

This work is licensed under the Creative Commons Attribution International License (CC BY). http://creativecommons.org/licenses/by/4.0/

(c) (i) Open Access

\section{Abstract}

The Hantzsch amide derivatives 1 are prepared by reaction of a mixture of two moles of benzoylacetone, aqueous ammonia and aromatic aldehydes. Also, the reaction of benzoylacetone with a mixture of urea or thiourea and aromatic aldehydes afforded pyrimidine derivatives $2 \mathrm{a}-\mathrm{h}$. Pyridinethione derivative 3 was reacted with $\alpha$-haloketones and $\alpha$-halonitriles 4 a-e to afford the $S$-alkylated derivatives 5a-e which cyclized into $6 \mathrm{~b}-\mathrm{e}$ and 7 . Reactions of compound 7 with glacial acetic acid/acetic anhydride gave 8 which led to $9 \mathrm{a}$ and $9 \mathrm{~b}$ on treatment with ammonium acetate/acetic acid and aniline. Also, treatment of 7 with formamide, hydrazine hydrate and benzoyl isothiocyanate afforded 10, 11 and 13. Reactions of 3 with arylidenemalononitrile 14 in ethanolic triethylamine yielded 1:1 addact 17a-c.

\section{Keywords}

Pyridines, Pyrimidines, Pyridinthione, Pyridothienopyrimidine and Isoquinolines

Subject Areas: Analytical Chemistry, Organic Chemistry

\section{Introduction}

Polyfunctionally substituted 1,4-dihydropyridines have been widely explored as cardiovascular agents. Nifedipine has been approved for clinical use as an antianginal agent and represents the prototype 1,4-dihydropyridine (DHP) structure found useful in both antianginal and antihypertensive therapy [1]. Also, the pyridinethione rings

\footnotetext{
${ }^{*}$ Corresponding author.
}

How to cite this paper: Hussein, A.H.M., Abu-Shanab, F.A. and Mousa, S.A.H.S. (2015) Benzoylacetone as a Building Block in Heterocyclic Synthesis: Synthesis of Polyfunctionally Substituted Pyridinethione and Its Derivatives. Open Access Library Journal, 2: e1274. http://dx.doi.org/10.4236/oalib.1101274 
have proved to be an interesting class of heterocycles. Many of its derivatives are used as antibacterial [2]-[7] and antihypertensive [8]. In continuation of our previous interest work in the synthesis of variety of heterocyclic compounds from readily obtainable inexpensive starting materials [9] [10], we report here the utility of benzoylacetone for the synthesis of some novel heterocyclic compounds.

\section{Results and Discussion}

It has been found that the Hantzsch amide derivatives $\mathbf{1}$ were prepared by the one-pot cyclization reaction of a mixture of two moles of benzoylacetone, aqueous ammonia and aromatic aldehydes [11]. Compounds $\mathbf{1}$ were confirmed by its spectroscopic methods (IR, ${ }^{1} \mathrm{H}$ NMR, Mass) and elemental analysis. The ${ }^{1} \mathrm{H}$ NMR spectrum of compound 1a as an example, revealed a singlet signal at $\delta 1.88 \mathrm{ppm}$ assigned to two methyl function group, singlet signal at $\delta 5.10 \mathrm{ppm}$ assigned to pyridine $-4 \mathrm{H}$, singlet signal at $\delta 5.75 \mathrm{ppm}$ assigned to exchange $\mathrm{NH}$ function group and multiplt signals at $\delta 6.88-7.51 \mathrm{ppm}$ assigned to aromatic function group. Mass spectrum of compound 1a revealed a molecular ion peak at $\mathrm{m} / \mathrm{z}=393\left(\mathrm{M}^{+}\right)$corresponding to the molecular formula $\left(\mathrm{C}_{27} \mathrm{H}_{23} \mathrm{NO}_{2}\right)$, Scheme 1 .

Also, the reaction of benzoylacetone with a mixture of urea or thiourea and aromatic aldehydes in ethanol containing $\mathrm{HCl}$ afforded the expected pyrimidine derivatives 2a-h. Structure 2a-h was confirmed based on its spectroscopic data. Thus ${ }^{1} \mathrm{H}$ NMR spectrum of compound $\mathbf{2} \mathbf{g}$ for example exhibit the presence of singlet signal at $\delta \mathrm{H}=5.29 \mathrm{ppm}$ assigned for $4 \mathrm{H}$-pyrimidine and singlet signals at $\delta \mathrm{H}=9.57$ and $10.24 \mathrm{ppm}$ assigned for two $\mathrm{NH}$ group. In addition, the Mass spectrum of compund $\mathbf{2 b}$ revealed a molecular ion peak at $\mathrm{m} / \mathrm{z}=326\left(\mathrm{M}^{+}\right)$corresponding to molecular formula $\left(\mathrm{C}_{18} \mathrm{H}_{15} \mathrm{ClN}_{2} \mathrm{O}_{2}\right)$, Scheme 2 .

The reactivity of pyridinethione $\mathbf{3}$ was also investigated. So, it has been found that pyridinethione derivative [12] $\mathbf{3}$ was reacted with $\alpha$-haloketones and $\alpha$-halonitriles $\mathbf{4 a - e}$ in refluxing ethanol containing sodium acetate to afford the S-alkylated derivatives 5a-e. The structure of 5a-e was established based on the elemental analysis and spectral data. The IR spectrium of compound $\mathbf{5 a}$ for examples exhibited the presence of the absorption band of cyano function group at $v=2216 \mathrm{~cm}^{-1}$ and absorption band of carbonyl of ester at $v=1734 \mathrm{~cm}^{-1}$. The ${ }^{1} \mathrm{H}$ NMR spectrum of compound 5a revealed a triplet signal at $\delta 1.18 \mathrm{ppm}$ assigned to methyl function group, a<smiles>[R]C1(C(=O)c2ccccc2)C(C(=O)O[NH2+][CH-]CC(C)=O)=C(C)NC(C)=C1C(=O)c1ccccc1</smiles>

$(\mathbf{1 a}, \mathbf{b})$

a, $\mathrm{R}=\mathrm{Ph}$

b, $\mathrm{R}=4-\mathrm{Cl}-\mathrm{C}_{6} \mathrm{H}_{4}$

Scheme 1. Synthesis of pyridine derivatives.

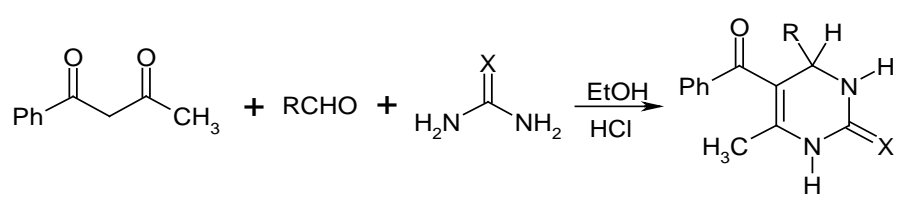

(2a-h)

\begin{tabular}{l|ll} 
2 & $\mathrm{R}$ & $\mathrm{X}$ \\
\hline $\mathbf{a}$ & $\mathrm{Ph}$ & $\mathrm{O}$ \\
b & $4-\mathrm{Cl}-\mathrm{C}_{6} \mathrm{H}_{4}$ & $\mathrm{O}$ \\
c & $4-\mathrm{CH}_{3}-\mathrm{C}_{6} \mathrm{H}_{4}$ & $\mathrm{O}$ \\
d & $4-\mathrm{CH}_{3} \mathrm{O}-\mathrm{C}_{6} \mathrm{H}_{4}$ & $\mathrm{O}$ \\
e & $\mathrm{Ph}$ & $\mathrm{S}$ \\
f & $4-\mathrm{Cl}^{-} \mathrm{C}_{6} \mathrm{H}_{4}$ & $\mathrm{~S}$ \\
g & $4-\mathrm{CH}_{3}-\mathrm{C}_{6} \mathrm{H}_{4}$ & $\mathrm{~S}$ \\
h & $4-\mathrm{CH}_{3} \mathrm{O}-\mathrm{C}_{6} \mathrm{H}_{4}$ & $\mathrm{~S}$
\end{tabular}

Scheme 2. Synthesis of pyrimidine derivatives. 
singlet signal at $\delta 2.50 \mathrm{ppm}$ assigned to methyl function group, a singlet signal at $\delta 4.01 \mathrm{ppm}$ assigned to methylene function group, a qurtet signal at $\delta 4.14 \mathrm{ppm}$ assigned to methylene function group, singlet signal at $\delta$ $7.20 \mathrm{ppm}$ assigned to ring- $\mathrm{H}$, and multiplt signals at $\delta 7.34-7.98 \mathrm{ppm}$ assigned to aromatic function group.

Compounds $\mathbf{5 b}$-e were cyclized into the corresponding thieno[2,3-b]pyridine derivatives $\mathbf{6 b}-\mathbf{b}$ upon boiling in ethanolic sodium ethoxide. The IR spectra of compounds $\mathbf{6 b}-\mathbf{e}$ exhibited the absence of the absorption band due to cyano function group and appearance of the absorption bands due to amino function group at $v=34,863,340$ $\mathrm{cm}^{-1}$ for compound $\mathbf{6 d}$. The ${ }^{1} \mathrm{H}$ NMR spectrum of compound (6b) for example, revealed a singlet signal at $\delta$ $2.81 \mathrm{ppm}$ assigned to methyl function group, singlet signal at $\delta 4.91 \mathrm{ppm}$ assigned to $\mathrm{NH}_{2}$ group, and multiplt signals at $\delta 7.46-8.07 \mathrm{ppm}$ assigned to aromatic function group.

A solid evidence for the structure of compounds $\mathbf{6 b}-\mathbf{e}$ came from its synthesis by another route by conducting the reaction between compound $\mathbf{3}$ and $\alpha$-halocompounds $\mathbf{4} \mathbf{b}-\mathbf{e}$ in boiling solution of ethanolic sodium ethoxide (m.p., mix. m.p. and TLC), Scheme 3.

In contrast to the behavior of compound 3 to $\alpha$-halocarbonyl compunds. It reacted with ethyl chloroacetate under refluxing in ethanol containing a few grams of sodium acetate to afford compound $\mathbf{5 a}$ which then cyclized into compound (7) instead of compound $\mathbf{6 a}$ in boiling ethanolic sodium ethoxide. The structure of compund $\mathbf{7}$ was assigned by elemental and spectral data. The ${ }^{1} \mathrm{H}$ NMR spectrum indicated the absence of ethoxy carbonyl group. The formation of this product is assumed to proceed via Thorpe cyclization followed by base hydrolysis of the ester group to the acid group, Scheme 4.

Reactions of compound 7 with glacial acetic acid in the presence of acetic anhydride gave 4,6-dimethyl-2phenyl-7-oxa-9-thia-1,5-diazafluoren-8-one 8. Treatment of compound 8 with ammonium acetate in boiling acetic acid led to the formation of pyridothienopyrimidine derivative $\mathbf{9 a}$.

Also, treatment of compound $\mathbf{8}$ with aniline in acetic acid afforded the pyridothienopyrimidine derivative $\mathbf{9 b}$. The structure of compounds 9a,b were established by spectral data (IR, ${ }^{1} \mathrm{H}$ NMR) and microanalysis. The ${ }^{1} \mathrm{H}$ NMR spectrum of compound 9a revealed a singlet signal at $\delta 2.56$ and $3.01 \mathrm{ppm}$ assigned to two methyl function group, and multiplt signals at $\delta 7.55-8.22 \mathrm{ppm}$ assigned to aromatic and singlet signal at $\delta 12.8 \mathrm{ppm}$ assigned to exchange $\mathrm{NH}$ function group group.

On the other hand, compound 7 was treated with formamide to afford 4-methyl-2-phenyl-7H-9-thia-1,5,7triazafluoren-8-one 10. The ${ }^{1} \mathrm{H}$ NMR spectrum of compound $\mathbf{1 0}$ revealed a singlet signal at $\delta 2.89 \mathrm{ppm}$ assigned to methyl function group, multiplt signals at $\delta 7.49-8.19 \mathrm{ppm}$ assigned to aromatic function group and hump signal at $\delta 12.82$ assigned to $\mathrm{NH}$ group.

Also, compound $\mathbf{7}$ was treated with hydrazine hydrate to afford the hydrazide derivative 11. Compound $\mathbf{1 3}$ was obtained by reaction of compound 7 with benzoyl isothiocyanate in anhydrous acetone solution through the thiourea intermediate (12). Mass spectrum of compound 13 revealed a molecular ion peak at $\mathrm{m} / \mathrm{z}=429\left(\mathrm{M}^{+}\right)$ corresponding to molecular formula $\left(\mathrm{C}_{23} \mathrm{H}_{15} \mathrm{~N}_{3} \mathrm{O}_{2} \mathrm{~S}_{2}\right)$ Scheme 5 .

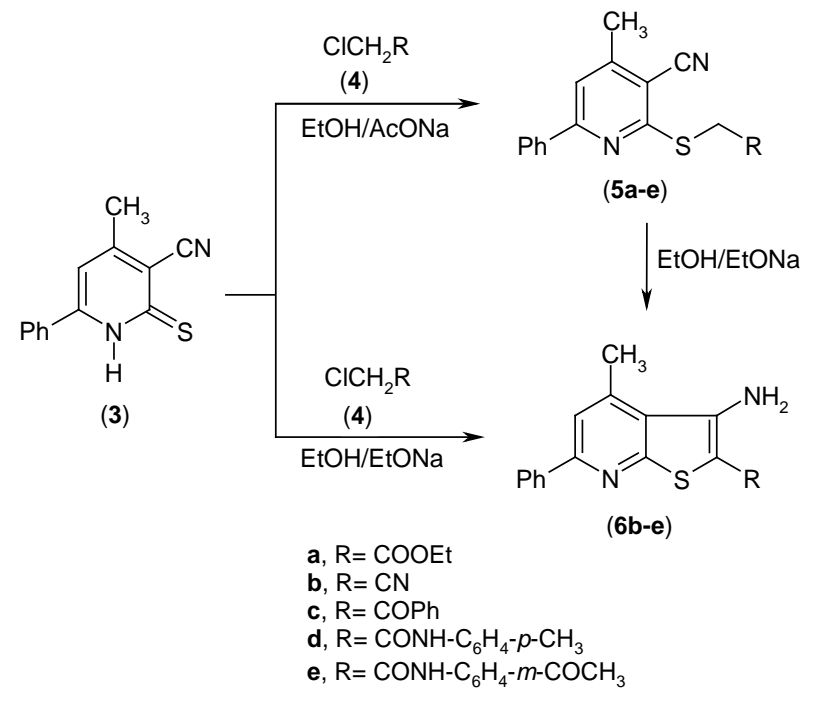

Scheme 3. Synthesis of thienopyridine derivatives. 


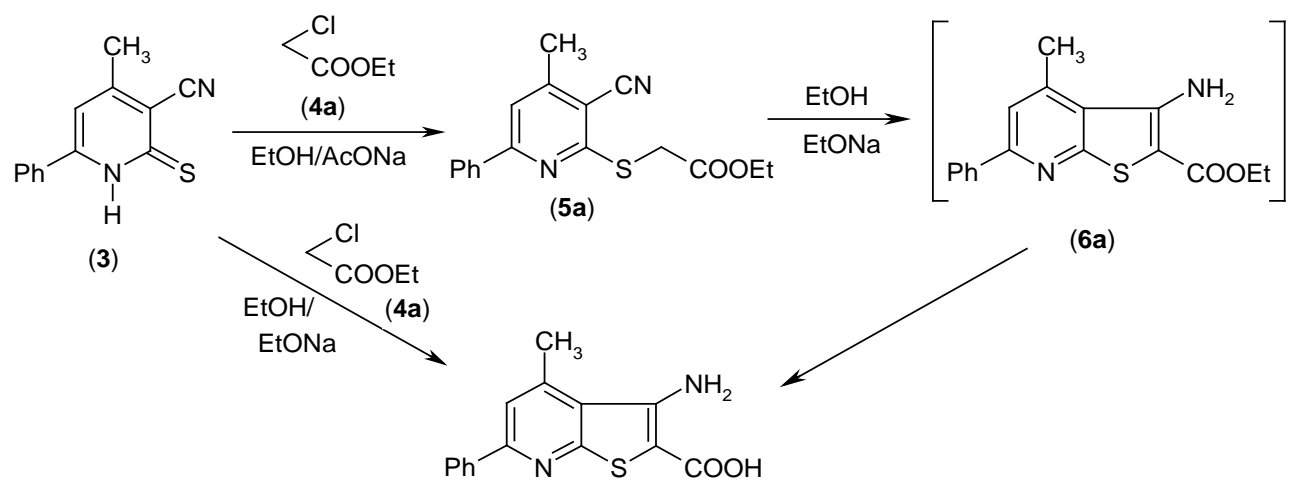

(7)

Scheme 4. Synthesis of 0-aminocarboxylic acid derivatives.<smiles>Cc1cc(-c2ccccc2)nc2sc(C(=O)NN)c(N)c12</smiles>

(11)<smiles>NCCCCNN</smiles><smiles>Cc1cc(-c2ccccc2)nc2sc3c(=O)[nH]cnc3c12</smiles>

(10)<smiles>CCCCCCC(N)=O</smiles><smiles>Cc1cc(-c2ccccc2)nc2sc(C(=O)O)c(N=S)c12</smiles>

(12)<smiles></smiles>

(13)<smiles>Cc1nc2c(sc3nc(-c4ccccc4)cc(C)c32)c(=O)o1</smiles>

(7)<smiles>[R]n1c(C)nc2c(sc3nc(-c4ccccc4)cc(C)c32)c1=O</smiles>

$(9 a, b)$

a, $R=H$

b, $\mathrm{R}=\mathrm{Ph}$

\section{Scheme 5. Synthesis or tricyclic compounds.}

The utility of the methyl heteroaromatic carbonitriles as bulding blocks for the synthesis of condensed azines has been examined [13]. So, the reaction of compound $\mathbf{3}$ with an equimolar amount of arylidenemalononitrile $\mathbf{1 4}$ in ethanolic triethylamine yielded 1:1 addact 17a-c. Compounds 17a-c were confirmed by spectroscopic data and elemental analysis. The ${ }^{1} \mathrm{H}$ NMR spectrum of compound 17a revealed revealed a singlet signal at $\delta 6.85$ ppm assigned to ring- $\mathrm{H}$, multiplt signals at $\delta 7.35-7.75 \mathrm{ppm}$ assigned to aromatic function group and $\mathrm{NH}_{2}$ and hump signal at $\delta 8.01$ assigned to NH group. Mass spectrum of compound 17a revealed a molecular ion peak at $m / z=387\left(\mathrm{M}^{+}\right)$corresponding to molecular formula $\left(\mathrm{C}_{22} \mathrm{H}_{14} \mathrm{ClN}_{3} \mathrm{~S}\right)$.

The formation of compound $\mathbf{1 7}$ is assumed to proceed via the addition of the methyl anionic center of the conjugated base of compound $\mathbf{3}$ to the activated double bond in compound $\mathbf{1 4}$ to afford the nonisolable intermediate 15 which undergoes cycliztion and aromatization under the reaction conditions to give the final product (isoquinoline derivative) 17, Scheme 6. 

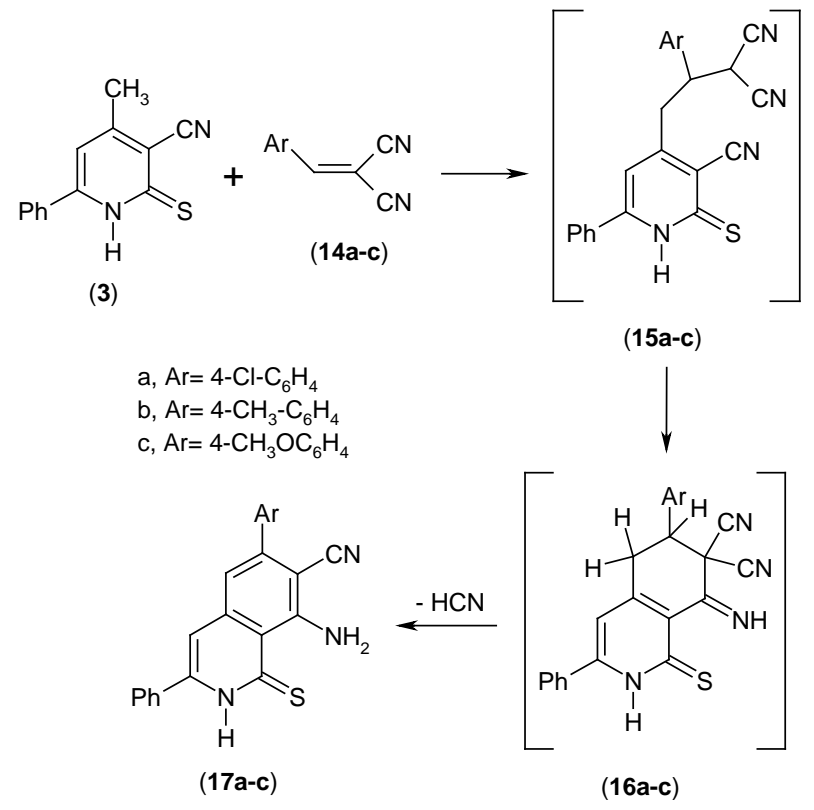

Scheme 6. Synthesis of isoquinolines.

\section{Experimental}

Preparation of 4H-pyridine derivative (1a,b). General procedure:

A mixture of benzoylacetone $(3.24 \mathrm{~g}, 20 \mathrm{mmol})$, benzaldehyde $(1.06 \mathrm{~g}, 10 \mathrm{mmol})$ or p-chlorobenzaldehyde $(1.41 \mathrm{~g}, 10 \mathrm{mmol})$ and aqueous ammonia $(3 \mathrm{~mL}, 33 \%)$ in ethanol $(20 \mathrm{~mL})$ was refluxed for $3 \mathrm{~h}$. The product so formed after cooling was collected by filtration and recrystallised from the appropriate solvent.

Preparation of (5-benzoyl-2,6-dimethyl-4-phenyl-1,4-dihydropyridin-3-yl)phenylmethanone (1a):

The title compound was prepared by the method described above and the product obtained in yield ( $2.65 \mathrm{~g}$, $67.43 \%$ ) was purified by recrystallisation from benzene/petrolum ether as yellow crystals, m.p. $210^{\circ} \mathrm{C}-212^{\circ} \mathrm{C}$; IR: $v_{\max }$ at $3296(\mathrm{NH})$ and $1664 \mathrm{~cm}^{-1}(\mathrm{C}=\mathrm{O}) ;{ }^{1} \mathrm{H}$ NMR $\left[\mathrm{CDCl}_{3}\right]$ : $\delta \mathrm{H}$ at $1.88\left(\mathrm{~s}, 6 \mathrm{H}, 2 \mathrm{CH}_{3}\right), 5.10(\mathrm{~s}, 1 \mathrm{H}, 4 \mathrm{H}-\mathrm{py}-$ ridine), 5.75 (s, $1 \mathrm{H}$, exch., $\mathrm{NH}$ ) and $6.88-7.51 \mathrm{ppm}(\mathrm{m}, 15 \mathrm{H}, \mathrm{Ar}) ; \mathrm{MS}: \mathrm{M}^{+}$at $\mathrm{m} / \mathrm{z}$ 393; Anal. Calcd for $\mathrm{C}_{27} \mathrm{H}_{23} \mathrm{NO}_{2}$ : C 82.42 H 5.89, N 3.56. Found: C 82.25, H 5.78, N 3.45\%.

Preparation of [5-benzoyl-4-(4-chlorophenyl)-2,6-dimethyl-1,4-dihydropyridin-3-yl)phenylmethanone (1b):

The title compound was prepared by the method described above and the product obtained in yield ( $2.65 \mathrm{~g}$, $67.43 \%$ ) was purified by recrystallisation from benzene/petrolum ether as yellow crystals, m.p. $245^{\circ} \mathrm{C}-247^{\circ} \mathrm{C}$; IR: $v_{\max }$ at $3297(\mathrm{NH})$ and $1667 \mathrm{~cm}^{-1}(\mathrm{C}=\mathrm{O})$; Anal. Calcd for $\mathrm{C}_{27} \mathrm{H}_{22} \mathrm{ClNO}_{2}$ : C 75.78, H 5.18, N 3.27. Found: C 75.60, H 5.07, N 3.14\%.

Preparation of pyrimidine derivative (2a-h). General procedure:

A mixture of benzoylacetone $(1.62 \mathrm{~g}, 10 \mathrm{mmol})$, urea $(0.60 \mathrm{~g}, 10 \mathrm{mmol})$ or thiourea $(0.76 \mathrm{~g}, 10 \mathrm{mmol})$, the appropriate aldehyde $(10 \mathrm{mmol})$ and 2 - 3 drops of $\mathrm{HCl}(37 \%)$ in ethanol $(10 \mathrm{~mL})$ was refluxed for $3 \mathrm{~h}$. The result was cooled at $0^{\circ} \mathrm{C}$ and the precipitate so formed was filtered off and then washed with ethanol and recrystallised from the appropriate solvent.

Preparation of 5-benzoyl-6-methyl-4-phenyl-3,4-dihydro-1H-pyrimidin-2-one (2a):

The title compound was prepared by the method described above using urea and benzaldehyde $(1.06 \mathrm{~g}, 10$ $\mathrm{mmol})$. The product obtained in yield $(2.20 \mathrm{~g}, 75.86 \%)$ was purified by recrystallisation from ethanol as yellow crystals, m.p. $218^{\circ} \mathrm{C}-220^{\circ} \mathrm{C}$; IR: $v_{\max }$ at $3298(\mathrm{NH})$ and $1702 \mathrm{~cm}^{-1}(\mathrm{C}=\mathrm{O})$; Anal. Calcd for $\mathrm{C}_{18} \mathrm{H}_{16} \mathrm{~N}_{2} \mathrm{O}_{2}$ : C 73.96, H 5.52, N 9.58. Found: C 73.78, H 5.41, N 9.46\%.

Preparation of 5-benzoyl-4-(4-chlorophenyl)-6-methyl-3,4-dihydro-1H-pyrimidin-2-one (2b):

The title compound was prepared by the method described above using urea and p-chlorobenzaldehyde (1.41 g, $10 \mathrm{mmol})$. The product obtained in yield $(2.19 \mathrm{~g}, 67.59 \%)$ was purified by recrystallisation from ethanol as yellow crystals, m.p. $232^{\circ} \mathrm{C}-234^{\circ} \mathrm{C}$; IR: $v_{\max }$ at $3288(\mathrm{NH})$ and $1706 \mathrm{~cm}^{-1}(\mathrm{C}=\mathrm{O})$; MS: $\mathrm{M}^{+}$at $\mathrm{m} / \mathrm{z} 326$ and $\mathrm{M}^{+2}$ at 
m/z 328; Anal. Calcd for $\mathrm{C}_{18} \mathrm{H}_{15} \mathrm{ClN}_{2} \mathrm{O}_{2}$ : C 66.16, H 4.63, N 8.57. Found: C 66.00, H 4.51, N 8.43\%.

Preparation of 5-benzoyl-6-methyl-4-p-tolyl-3,4-dihydro-1H-pyrimidin-2-one (2c):

The title compound was prepared by the method described above using urea and p-methylbenzaldehyde (1.20 g, $10 \mathrm{mmol})$. The product obtained in yield (1.93 g, 63.47\%) was purified by recrystallisation from ethanol as yellow crystals, m.p. $235^{\circ} \mathrm{C}-237^{\circ} \mathrm{C}$; IR: $v_{\max }$ at $3236(\mathrm{NH})$ and $1690 \mathrm{~cm}^{-1}(\mathrm{C}=\mathrm{O})$; Anal. Calcd for $\mathrm{C}_{19} \mathrm{H}_{18} \mathrm{~N}_{2} \mathrm{O}_{2}$ : C 74.49, H 5.92, N 9.14. Found: C 74.33, H 5.80, N 9.01\%.

Preparation of 5-benzoyl-4-(4-methoxyphenyl)-6-methyl-3,4-dihydro-1H-pyrimidin-2-one (2d):

The title compound was prepared by the method described above using urea and p-methoxylbenzaldehyde (1.36 g, $10 \mathrm{mmol})$. The product obtained in yield (1.95 g, 60.94\%) was purified by recrystallisation from ethanol as orange crystals, m.p. $242^{\circ} \mathrm{C}-244^{\circ} \mathrm{C}$; IR: $v_{\max }$ at $3232(\mathrm{NH})$ and $1698 \mathrm{~cm}^{-1}(\mathrm{C}=\mathrm{O})$; ${ }^{1} \mathrm{H} \mathrm{NMR}$ [DMSO]: $\delta \mathrm{H}$ at 2.54 (s, 3H, $\mathrm{CH}_{3}$ ), 3.91 (s, 3H, $\left.\mathrm{OCH}_{3}\right) 5.37$ (s, 1H, 4H-pyrimidine), 7.12 - 7.76 (m, 9H, Ar), 8.53 (s, 1H, exch., $\mathrm{NH}$ ) and 9.21 ppm (br., 1H, exch., $\mathrm{NH}$ ); Anal. Calcd for $\mathrm{C}_{19} \mathrm{H}_{18} \mathrm{~N}_{2} \mathrm{O}_{3}$ : C 70.79, H 5.63, N 8.69. Found: C 70.62, H 5.52, N 8.55\%.

Preparation of (6-methyl-4-phenyl-2-thioxo-1,2,3,4-tetrahydropyri-midin-5-yl)phenylmethanone (2e):

The title compound was prepared by the method described above using thiourea and benzaldehyde (1.06 g, 10 $\mathrm{mmol})$. The product obtained in yield $(2.11 \mathrm{~g}, 68.95 \%)$ was purified by recrystallisation from ethanol as orange crystals, m.p. $246^{\circ} \mathrm{C}-248^{\circ} \mathrm{C}$; IR: $v_{\max }$ at $3282(\mathrm{NH})$ and $1660 \mathrm{~cm}^{-1}(\mathrm{C}=\mathrm{O})$; Anal. Calcd for $\mathrm{C}_{18} \mathrm{H}_{16} \mathrm{~N}_{2} \mathrm{OS}$ : C 70.10, H 5.23, N 9.08. Found: C 69.92, H 5.12, N 8.96\%.

Preparation of [4-(4-chlorophenyl)-6-methyl-2-thioxo-1,2,3,4-tetrahydropyrimidin-5-yl]phenylmethanone (2f):

The title compound was prepared by the method described above using thiourea and p-chlorobenzaldehyde (1.41 g, $10 \mathrm{mmol})$. The product obtained in yield (2.07 g, 60.88\%) was purified by recrystallisation from ethanol as orange crystals, m.p. $250^{\circ} \mathrm{C}-252^{\circ} \mathrm{C}$; IR: $v_{\max }$ at $3281(\mathrm{NH})$ and $1666 \mathrm{~cm}^{-1}(\mathrm{C}=\mathrm{O}) ; \mathrm{MS} \mathrm{M}^{+}$at $\mathrm{m} / \mathrm{z} 342$ and $\mathrm{M}^{+2}$ at $\mathrm{m} / \mathrm{z}$ 344; Anal. Calcd for $\mathrm{C}_{18} \mathrm{H}_{15} \mathrm{ClN}_{2} \mathrm{OS}$ : C 63.06, H 4.41, N 8.17. Found: C 62.90, H 4.29, N 8.04\%.

Preparation of (6-methyl-2-thioxo-4-p-tolyl-1,2,3,4-tetrahydropyri-midin-5-yl)phenylmethanone (2g):

The title compound was prepared by the method described above using thiourea and p-methylbenzaldehyde ( $1.20 \mathrm{~g}, 10 \mathrm{mmol})$. The product obtained in yield $(1.88 \mathrm{~g}, 58.75 \%)$ was purified by recrystallisation from ethanol as orange crystals, m.p. $262^{\circ} \mathrm{C}-264^{\circ} \mathrm{C}$; IR: $v_{\max }$ at $3284(\mathrm{NH})$ and $1663 \mathrm{~cm}^{-1}(\mathrm{C}=\mathrm{O}) ;{ }^{1} \mathrm{H} \mathrm{NMR}$ [DMSO]: $\delta \mathrm{H}$ at 1.76 (s, 3H, $\mathrm{CH}_{3}$ ), 2.26 (s, 3H, $\left.\mathrm{CH}_{3}\right) 5.29$ (s, 1H, 4H-pyrimidine), 6.97 - 7.65 (m, 9H, Ar), 9.57 (s, 1H, exch., $\mathrm{NH}$ ) and 10.24 ppm (s, 1H, exch., NH); Anal. Calcd for $\mathrm{C}_{19} \mathrm{H}_{18} \mathrm{~N}_{2} \mathrm{OS}$ : C 70.78, H 5.63, N 8.69. Found: C 70.61, H 5.51, N 8.56\%.

Preparation of [4-(4-methoxyphenyl)-6-methyl-2-thioxo-1,2,3,4-tetrahydropyrimidin-5-yl]phenylmethanone (2h):

The title compound was prepared by the method described above using thiourea and p-methoxylbenzaldehyde (1.36 g, $10 \mathrm{mmol})$. The product obtained in yield $(2.10 \mathrm{~g}, 62.50 \%)$ was purified by recrystallisation from ethanol as orange crystals, m.p. $268^{\circ} \mathrm{C}-270^{\circ} \mathrm{C}$; IR: $v_{\max }$ at $3215(\mathrm{NH})$ and $1671 \mathrm{~cm}^{-1}(\mathrm{C}=\mathrm{O})$; Anal. Calcd for $\mathrm{C}_{19} \mathrm{H}_{18} \mathrm{~N}_{2} \mathrm{O}_{2} \mathrm{~S}$ : C 67.43, H 5.36, N8.28. Found: C 67.45, H 5.24, N 8.15\%.

Preparation of 2-substituted-mercapto-4-methyl-6-phenylpyridine-3-carbonitrile (5a-e). General procedure:

To a solution of mercaptopyridine (3) $(2.66 \mathrm{~g}, 10 \mathrm{mmol})$ in ethanol (30 mL) and sodium acetate (10 mmol), the appropriate $\alpha$-halocompounds (4a-e) (10 mmol) was added. The reaction mixture was refluxed for one hour. After cooling, the solid product formed was collected by filtration washed with water several times and recrystallised from the appropriate solvent.

Preparation of (3-cyano-4-methyl-6-phenylpyridin-2-ylsulfanyl)-acetic acid ethyl ester (5a):

The title compound was prepared by the method described above using ethyl chloroacetate (4a) (1.22 g, 10 mmol). The product obtained in yield (2.6 g, 83.33\%) was purified by recrystallisation from ethanol as white crystals, m.p. $130{ }^{\circ} \mathrm{C}-132^{\circ} \mathrm{C}$; IR: $v_{\max }$ at $2216(\mathrm{C} \equiv \mathrm{N})$ and $1734 \mathrm{~cm}^{-1}(\mathrm{C}=\mathrm{O}) ;{ }^{1} \mathrm{H} \mathrm{NMR}\left[\mathrm{CDCl}_{3}\right]: \delta \mathrm{H}$ at $1.18(\mathrm{t}, 3 \mathrm{H}$, $\left.\mathrm{CH}_{3}\right), 2.50$ (s, 3H, $\left.\mathrm{CH}_{3}\right), 4.01\left(\mathrm{~s}, 2 \mathrm{H}, \mathrm{CH}_{2}\right), 4,14\left(\mathrm{q}, 2 \mathrm{H}, \mathrm{CH}_{2}\right), 7.20$ (s, 1H, ring-H) and $7.34-7.98 \mathrm{ppm}(\mathrm{m}, 5 \mathrm{H}$, Ar); Anal. Calcd for $\mathrm{C}_{17} \mathrm{H}_{16} \mathrm{~N}_{2} \mathrm{O}_{2} \mathrm{~S}$ : C 65.36, H 5.16, N 8.97. Found: C 65.18, H 5.03, N 8.85\%.

Preparation of 2-cyanomethylsulfamyl-4-methyl-6-phenylnicotino-nitrile (5b):

The title compound was prepared by the method described above using chloroacetonitrile (4b) (0.75 g, 10 mmol). The product obtained in yield ( $2.44 \mathrm{~g}, 92.08 \%)$ was purified by recrystallisation from ethanol as white crystals, m.p. $155^{\circ} \mathrm{C}-157^{\circ} \mathrm{C}$; IR: $v_{\max }$ at $2980\left(\mathrm{C}-\mathrm{H}\right.$, aliph) and $2216 \mathrm{~cm}^{-1}(\mathrm{C} \equiv \mathrm{N})$; anal. Calcd for $\mathrm{C}_{15} \mathrm{H}_{11} \mathrm{~N}_{3} \mathrm{~S}$ : C 
67.90, H 4.18, N 15.84. Found: C 67.71, H 4.05, N 15.68\%.

Preparation of 4-methyl-2-(2-oxo-2-phenylethylsulfanyl)-6-phenyl-nicotinonitrile (5c):

The title compound was prepared by the method described above using phenacyl bromide (4c) (1.99 g, 10 $\mathrm{mmol})$. The product obtained in yield $(2.72 \mathrm{~g}, 79.07 \%)$ was purified by recrystallisation from ethanol as red crystals, m.p. $162^{\circ} \mathrm{C}-164^{\circ} \mathrm{C}$; IR: $v_{\max }$ at $2990\left(\mathrm{C}-\mathrm{H}\right.$, aliph), $2212(\mathrm{C} \equiv \mathrm{N})$ and $1682 \mathrm{~cm}^{-1}(\mathrm{C}=\mathrm{O})$; Anal. Calcd for $\mathrm{C}_{21} \mathrm{H}_{16} \mathrm{~N}_{2} \mathrm{OS}$ : C 73.23, H 4.68, N 8.13. Found: C 73.04, H 4.55, N 8.01\%.

Preparation of 2-(3-cyano-4-methyl-6-phenylpyridin-2-ylsulfanyl)-N-p-tolylacetamide (5d):

The title compound was prepared by the method described above using 2-chloro-N-p-tolyl-acetamide (4d) $(1.83 \mathrm{~g}, 10 \mathrm{mmol})$. The product obtained in yield $(3.13 \mathrm{~g}, 83.91 \%)$ was purified by recrystallisation from ethanol as yellow crystals, m.p. $158^{\circ} \mathrm{C}-160^{\circ} \mathrm{C}$; IR: $v_{\max }$ at $3250(\mathrm{NH}), 2215(\mathrm{C} \equiv \mathrm{N})$ and $1665 \mathrm{~cm}^{-1}(\mathrm{C}=\mathrm{O})$; Anal. Calcd for $\mathrm{C}_{22} \mathrm{H}_{19} \mathrm{~N}_{3} \mathrm{OS}$ : C 70.75, H 5.13, N 11.25. Found: C 70.58, H 5.00, N 11.09\%.

Preparation of N-(3-acetylphenyl)-2-(3-cyano-4-methyl-6-phenyl-pyridin-2-ylsulfanyl)acetamide (5e):

The title compound was prepared by the method described above using N-(3-acetylphenyl)-2-chloroacetamide (4e) $(2.11 \mathrm{~g}, 10 \mathrm{mmol})$. The product obtained in yield (3.08 g, 76.81\%) was purified by recrystallisation from ethanol as orange crystals, m.p. $170^{\circ} \mathrm{C}-172^{\circ} \mathrm{C}$; IR: $v_{\max }$ at $3268(\mathrm{NH}), 2924(\mathrm{C}-\mathrm{H}$, aliph) $2216(\mathrm{C} \equiv \mathrm{N})$ and 1672 $\mathrm{cm}^{-1}\left(\mathrm{COCH}_{3}\right)$; Anal. Calcd for $\mathrm{C}_{23} \mathrm{H}_{19} \mathrm{~N}_{3} \mathrm{O}_{2} \mathrm{~S}$ : C 68.81, H 4.77, N 10.47. Found: C 68.65, H 4.64, N 10.33\%.

Preparation of thieno[2,3-b]pyridine derivatives (6b-e) and (7). General procedure: Method A:

A mixture of 2-substituted-mercapto-4-methyl-6-phenylpyri-dine-3-carbonitrile (5a-e) (10 mmol) and sodium ethoxide ( $30 \mathrm{~mL}, 0.25 \mathrm{~g}$ sodium metal) was heated under reflux for about $2 \mathrm{~h}$. The reaction mixture was poured on ice cold water, the solid product was recovered by filtration to give the title compound and recrystallised from the appropriate solvent.

Method B:

A mixture of mercaptopyridine (3) $(2.66,10 \mathrm{mmol})$, sodium ethoxide ( $30 \mathrm{~mL}, 0.5 \mathrm{~g}$ sodium metal) and the appropriate $\alpha$-halocompounds (4a-e) (10 mmol) was heated under reflux for about $2 \mathrm{~h}$. The reaction mixture was poured on ice cold water, the solid product was recovered by filtration to give the title compound and recrystallised from the appropriate solvent.

Preparation of 3-amino-4-methyl-6-phenylthieno[2,3-b]pyridine-2-carbonitrile (6b):

The title compound was prepared by the method described above using chloroacetonitrile (4b) ( $0.75 \mathrm{~g}, 10$ $\mathrm{mmol})$. The product obtained in yield $(2.20 \mathrm{~g}, 83.02 \%)$ was purified by recrystallisation from ethanol as yellow crystals, m.p. $254^{\circ} \mathrm{C}-256^{\circ} \mathrm{C}$; IR: $v_{\max }$ at $333,4-323,0\left(\mathrm{NH}_{2}\right)$ and $2186 \mathrm{~cm}^{-1}(\mathrm{C} \equiv \mathrm{N}) ;{ }^{1} \mathrm{H} \mathrm{NMR}\left[\mathrm{CDCl}_{3}\right]: \delta \mathrm{H}$ at 2.81 (s, $\left.3 \mathrm{H}, \mathrm{CH}_{3}\right), 4.91\left(\mathrm{~s}, 2 \mathrm{H}, \mathrm{NH}_{2}\right), 7.46-7.58(\mathrm{~m}, 3 \mathrm{H}, \mathrm{Ar}+$ ring-H) and $8.02-8.07 \mathrm{ppm}(\mathrm{m}, 2 \mathrm{H}, \mathrm{Ar})$; Anal. Calcd for $\mathrm{C}_{15} \mathrm{H}_{11} \mathrm{~N}_{3} \mathrm{~S}$ : C 67.90, H 4.18, N 15.84. Found: C 67.70, H 4.09, N 15.73\%.

Preparation of (3-amino-4-methyl-6-phenylthieno[2,3-b]pyridin-2-yl)phenylmethanone (6c):

The title compound was prepared by the method described above using phenacyl bromide (4c) (1.99 g, 10 $\mathrm{mmol})$. The product obtained in yield $(2.54 \mathrm{~g}, 73.84 \%)$ was purified by recrystallisation from ethanol as red crystals, m.p. $248^{\circ} \mathrm{C}-250^{\circ} \mathrm{C}$; IR: $v_{\max }$ at $343,2-332,0\left(\mathrm{NH}_{2}\right)$ and $1707 \mathrm{~cm}^{-1}(\mathrm{C}=\mathrm{O}) ;{ }^{1} \mathrm{H}$ NMR [DMSO]: $\delta \mathrm{H}$ at $2.72\left(\mathrm{~s}, 3 \mathrm{H}, \mathrm{CH}_{3}\right)$ and 7.56, $8.20 \mathrm{ppm}\left(\mathrm{m}, 13 \mathrm{H}, \mathrm{Ar}+\mathrm{NH}_{2}+\right.$ ring-H); Anal. Calcd for $\mathrm{C}_{21} \mathrm{H}_{16} \mathrm{~N}_{2} \mathrm{OS}$ : C 73.23, $\mathrm{H}$ 4.68, N 8.13. Found: C 73.02, H 4.50, N 8.00\%.

Preparation of 3-amino-4-methyl-6-phenylthieno[2,3-b]pyridine-2-carboxylic acid p-tolylamide (6d):

The title compound was prepared by the method described above using 2-chloro-N-p-tolyl-acetamide (4d) $(1.83 \mathrm{~g}, 10 \mathrm{mmol})$. The product obtained in yield (2.76 g, 73.99\%) was purified by recrystallisation from ethanol as orange crystals, m.p. $240^{\circ} \mathrm{C}-242^{\circ} \mathrm{C}$; IR: $v_{\max }$ at $348,6-334,0 \mathrm{~cm}^{-1}\left(\mathrm{NH}_{2}, \mathrm{NH}\right) ;{ }^{1} \mathrm{H} \mathrm{NMR}\left[\mathrm{CDCl}_{3}\right]: \delta \mathrm{H}$ at 2.34 (s, 3H, $\left.\mathrm{CH}_{3}\right), 2.85$ (s, 3H, $\left.\mathrm{CH}_{3}\right), 6.45$ (s, 2H, exch., $\mathrm{NH}_{2}$ ) and $7.15-7.55,8.09 \mathrm{ppm}(\mathrm{m}, 11 \mathrm{H}, \mathrm{Ar}+\mathrm{NH}+$ ring-H); Anal. Calcd for $\mathrm{C}_{22} \mathrm{H}_{19} \mathrm{~N}_{3} \mathrm{OS}$ C 70.75, H 5.13, N 11.25. Found: C 70.58, H 5.01, N 11.11\%.

Preparation of 3-amino-4-methyl-6-phenylthieno[2,3-b]pyridine-2-carboxylic acid (3-acetylphenyl) amide (6e):

The title compound was prepared by the method described above using N-(3-acetylphenyl)-2-chloroacetamide (4e) $(2.11 \mathrm{~g}, 10 \mathrm{mmol})$. The product obtained in yield $(2.77 \mathrm{~g}, 69.08 \%)$ was purified by recrystallisation from ethanol as red crystals, m.p. $245^{\circ} \mathrm{C}-247^{\circ} \mathrm{C}$; IR: $v_{\max }$ at $346,5-332,7 \mathrm{~cm}^{-1}\left(\mathrm{NH}_{2}, \mathrm{NH}\right), 1670\left(\mathrm{COCH}_{3}\right)$; Anal. Calcd for $\mathrm{C}_{23} \mathrm{H}_{19} \mathrm{~N}_{3} \mathrm{O}_{2} \mathrm{~S}$ : C 68.81, H 4.77, N 10.47. Found: C 68.74, H 4.67, N 10.30\%.

Preparation of 3-amino-4-methyl-6-phenylthieno[2,3-b]pyridine-2-carboxylic acid (7):

The title compound was prepared by the method described above using ethyl chloroacetate (4a) (1.22 g, 10 $\mathrm{mmol})$. The product obtained in yield $(2.05 \mathrm{~g}, 72.18 \%)$ was purified by recrystallisation from ethanol as orange 
crystals, m.p. $265^{\circ} \mathrm{C}-267^{\circ} \mathrm{C}$; IR: $v_{\max }$ at $3415(\mathrm{OH}), 33,603,285\left(\mathrm{NH}_{2}\right)$ and $1670 \mathrm{~cm}^{-1}(\mathrm{C}=\mathrm{O}) ;{ }^{1} \mathrm{H}$ NMR [DMSO]: $\delta \mathrm{H}$ at $2.81\left(\mathrm{~s}, 3 \mathrm{H}, \mathrm{CH}_{3}\right), 6.36\left(\mathrm{~s}, 3 \mathrm{H}, \mathrm{NH}_{2}+\mathrm{OH}\right), 7.46-7.52(\mathrm{~m}, 3 \mathrm{H}, \mathrm{Ar}), 7.63(\mathrm{~s}, 1 \mathrm{H}$, ring-H) and 8.10 - 8.14 ppm (m, 2H, Ar); Anal. Calcd for $\mathrm{C}_{15} \mathrm{H}_{12} \mathrm{~N}_{2} \mathrm{O}_{2} \mathrm{~S}$ : C 63.36, H 4.25, N 9.85. Found: C 63.18, H 4.11, N $9.73 \%$.

Preparation of 4,6-dimethyl-2-phenyl-7-oxa-9-thia-1,5-diazafluoren-8-one (8):

3-Amino-4-methyl-6-phenylthieno[2,3-b]pyridine-2-carboxylic acid (7) (2.84 g, $10 \mathrm{mmol})$ was refluxed in acetic anhydride $(30 \mathrm{~mL})$ for $3 \mathrm{~h}$. The reaction mixture was left to stand at room temperature and the product so formed was collected by filtration. The product obtained in yield (1.88 g, 61.04\%) was purified by recrystallisation from dioxan as greenish crystals, m.p. $290^{\circ} \mathrm{C}-292^{\circ} \mathrm{C}$; IR: $v_{\max }$ at $1727 \mathrm{~cm}^{-1}(\mathrm{C}=\mathrm{O}) ;{ }^{1} \mathrm{H}$ NMR [DMSO]: $\delta \mathrm{H}$ at 2.59 (s, 3H, $\left.\mathrm{CH}_{3}\right), 2.99\left(\mathrm{~s}, 3 \mathrm{H}, \mathrm{CH}_{3}\right)$ and $7.51-7.62,8.12-8.25 \mathrm{ppm}(\mathrm{m}, 6 \mathrm{H}, \mathrm{Ar}+$ ring-H); Anal. Calcd for $\mathrm{C}_{17} \mathrm{H}_{12} \mathrm{~N}_{2} \mathrm{O}_{2} \mathrm{~S}$ : C 66.22, H 3.92, N 9.08. Found: C 66.05, H 3.81, N 8.95\%.

Preparation of pyridothienopyrimidine $(9 \mathrm{a}, \mathrm{b})$. General procedure:

A mixture of oxazine derivative (8) (3.08 g, $10 \mathrm{mmol}$ ) and ammonium acetate (20 mmol) or aniline (10 mmol) in acetic acid $(30 \mathrm{~mL})$ was heated under reflux for $3 \mathrm{~h}$. The solid product so formed after cooling was collected by filtration and recrystallised from the appropriate solvent.

Preparation of 4,6-dimethyl-2-phenyl-7H-9-thia-1,5,7-triazafluoren-8-one (9a):

The title compound was prepared by the method described above and the product obtained in yield (1.62 $\mathrm{g}$, $52.77 \%$ ) was purified by recrystallisation from DMF/EtOH as white crystals, m.p. $320^{\circ} \mathrm{C}-322^{\circ} \mathrm{C}$; IR: $v_{\max }$ at $3290(\mathrm{NH})$ and $1644 \mathrm{~cm}^{-1}(\mathrm{C}=\mathrm{O})$; ${ }^{1} \mathrm{H}$ NMR [DMSO]: $\delta \mathrm{H}$ at 2.56 (s, 3H, $\left.\mathrm{CH}_{3}\right), 3.01\left(\mathrm{~s}, 3 \mathrm{H}, \mathrm{CH}_{3}\right), 7.55-7.99$ (m, $6 \mathrm{H}, \mathrm{Ar}$ ), and 12.8 ppm (br., $1 \mathrm{H}$, exch., $\mathrm{NH}$ ); Anal. Calcd for $\mathrm{C}_{17} \mathrm{H}_{13} \mathrm{~N}_{3} \mathrm{OS}$ : C 66.43, H 4.26, N 13.67. Found: C 66.28, H 4.14, N 13.55\%.

Preparation of 4,6-dimethyl-2,7-diphenyl-7H-9-thia-1,5,7-triazafluoren-8-one (9b):

The title compound was prepared by the method described above and the product obtained in yield $(1.70 \mathrm{~g}$, $44.39 \%$ ) was purified by recrystallisation from DMF/dioxan as yellow, m.p. $310^{\circ} \mathrm{C}-312^{\circ} \mathrm{C}$; IR: $v_{\max }$ at 1729 $\mathrm{cm}^{-1}(\mathrm{C}=\mathrm{O})$; ${ }^{1} \mathrm{H}$ NMR [DMSO]: $\delta \mathrm{H}$ at $2.27\left(\mathrm{~s}, 3 \mathrm{H}, \mathrm{CH}_{3}\right), 3.08\left(\mathrm{~s}, 3 \mathrm{H}, \mathrm{CH}_{3}\right)$ and $7.55-8.25 \mathrm{ppm}(\mathrm{m}, 11 \mathrm{H}, \mathrm{Ar}+$ ring-H); Anal. Calcd for $\mathrm{C}_{23} \mathrm{H}_{17} \mathrm{~N}_{3} \mathrm{OS}$ : C 72.04, $\mathrm{H}$ 4.47, N 10.96. Found: C 71.88, H 4.36, N 10.82\%.

Preparation of 4-methyl-2-phenyl-7H-9-thia-1,5,7-triazafluoren-8-one (10):

A solution of 3-amino-4-methyl-6-phenylthieno[2,3-b]pyridine-2-carboxylic acid (7) (2.84 g, $10 \mathrm{mmol}$ ) in formamide $(10 \mathrm{~mL})$ was heated under reflux for $2 \mathrm{~h}$. The reaction mixture was poured on ice cold water and the solid product so formed was filtered off, washed with water several time. The product obtained in yield (1.89 g, 64.51\%) was purified by recrystallisation from $\mathrm{DMF} / \mathrm{EtOH}$ as brown crystals, m.p. $>300^{\circ} \mathrm{C}$; IR: $v_{\max }$ at 3225 $\mathrm{cm}^{-1}(\mathrm{NH}), 1678(\mathrm{C}=\mathrm{O})$; ${ }^{1} \mathrm{H}$ NMR [DMSO]: $\delta \mathrm{H}$ at $2.89\left(\mathrm{~s}, 3 \mathrm{H}, \mathrm{CH}_{3}\right), 7.49-8.19(\mathrm{~m}, 7 \mathrm{H}, \mathrm{Ar}+$ pyridine-H + pyrimidine-H) and 12.82 ppm (br., $1 \mathrm{H}$, exch., $\mathrm{NH}$ ); Anal. Calcd for $\mathrm{C}_{16} \mathrm{H}_{11} \mathrm{~N}_{3} \mathrm{OS}$ : C 65.51, H 3.78, N 14.32. Found: C 65.35, H 3.66, N 14.19\%.

Preparation of 3-amino-4-methyl-6-phenylthieno[2,3-b]pyridine-2-carboxylic acid hydrazide (11):

To a solution of 3-amino-4-methyl-6-phenylthieno[2,3-b]pyridine-2-carboxylic acid (7) (2.84 g, $10 \mathrm{mmol}$ ) in ethanol $(30 \mathrm{~mL})$, the hydrazine hydrate $(20 \mathrm{mmol})$ was added. The reaction mixture was refluxed for $3 \mathrm{~h}$. The product so formed was collected in yield $(2.06 \mathrm{~g}, 69.13 \%)$ and purified by recrystallisation from DMF/dioxan as white crystals, m.p. $298^{\circ} \mathrm{C}-300^{\circ} \mathrm{C}$; IR: $v_{\max }$ at $3386,3288 \mathrm{~cm}^{-1}\left(\mathrm{NH}_{2}, \mathrm{NH}\right) ;{ }^{1} \mathrm{H}$ NMR [DMSO]: $\delta \mathrm{H}$ at 2.80 (s, $\left.3 \mathrm{H}, \mathrm{CH}_{3}\right), 6.06\left(\mathrm{~s}, 2 \mathrm{H}\right.$, exch, $\left.\mathrm{NH}_{2}\right)$ and $7.62-8.06 \mathrm{ppm}\left(\mathrm{m}, 9 \mathrm{H}, \mathrm{Ar}+\mathrm{NH}_{2}+\mathrm{NH}+\right.$ ring-H); Anal. Calcd for $\mathrm{C}_{15} \mathrm{H}_{14} \mathrm{~N}_{4} \mathrm{OS}$ : C 60.38, H 4.73, N 18.78. Found: C 60.20, H 4.64, N 18.65\%.

Preparation of 7-benzoyl-4-methyl-2-phenyl-6-thioxo-6,7-dihydro-5H-9-thia-1,5,7-triazafluoren-8-one (13):

To a solution of 3-amino-4-methyl-6-phenylthieno[2,3-b]pyridine-2-carboxylic acid (7) (2.84 g, $10 \mathrm{mmol}$ ) in anhydrous acetone, benzoyl isothiocyanate $(10 \mathrm{mmol})$ (prepared in situ by reaction of ammonium thiocyanate $(0.76 \mathrm{~g})$ with benzoyl chloride $(1.41 \mathrm{~g})$ in anhydrous acetone under reflux for $10 \mathrm{~min}$.) was added. The reaction mixture was refluxed for $3 \mathrm{~h}$, then poured into cold water. The product obtained in yield $(2.75 \mathrm{~g}, 64.10 \%)$ was purified by recrystallisation from ethanol as orange crystals, m.p. $315^{\circ} \mathrm{C}-317^{\circ} \mathrm{C}$; IR: $v_{\max }$ at $3340(\mathrm{NH}), 1738$ $(\mathrm{C}=\mathrm{O})$ and $1685 \mathrm{~cm}^{-1}(\mathrm{C}=\mathrm{O})$; MS: $\mathrm{M}^{+}$at $\mathrm{m} / \mathrm{z}$ 429; Anal. Calcd for $\mathrm{C}_{23} \mathrm{H}_{15} \mathrm{~N}_{3} \mathrm{O}_{2} \mathrm{~S}_{2}$ : C 64.32, $\mathrm{H}$ 3.52, N 9.78. Found: C 64.16, H 3.41, N 9.66\%.

Reactions of pyridinethione (4.3) with arylidenemalononitrile (14). General procedure:

To a solution of pyridinethione (3) $(2.26 \mathrm{~g}, 10 \mathrm{mmol})$ in ethanol $(30 \mathrm{~mL})$ was added the arylidenemalononitrile (14) (10 mmol) and few drops of triethylamine. The reaction mixture was refluxed for four hours, then 
poured into ice-cold water and acidified by $\mathrm{HCl}$. The solid product so formed was collected by filtration, washed with water several times, dried and recrystallised from the proper solvent.

Preparation of 8-amino-6-(4-chlorophenyl)-3-phenyl-1-thioxo-1,2-dihydro-isoquinoline-7-carbonitrile (17a):

The title compound was prepared by the method described above using 2-(4-chlorobenzylidene)malononitrile (14a) (1.88 g, $10 \mathrm{mmol})$. The product obtained in yield (3.12 g, 80.52\%) was purified by recrystallisation from ethanol as red crystals, m.p. $160^{\circ} \mathrm{C}-162^{\circ} \mathrm{C}$; IR: $v_{\max }$ at $3360,3305,3223\left(\mathrm{NH}_{2}, \mathrm{NH}\right)$ and $2208 \mathrm{~cm}^{-1}(\mathrm{C} \equiv \mathrm{N}) ;{ }^{1} \mathrm{H}$ NMR [DMSO]: $\delta \mathrm{H}$ at 6.85 (s, 1H, ring-H), 7.35 - $7.75\left(\mathrm{~m}, 12 \mathrm{H}, \mathrm{Ar}+\mathrm{NH}_{2}\right.$ ) and $8.01 \mathrm{ppm}$ (br., $1 \mathrm{H}$, exch., $\left.\mathrm{NH}\right)$; MS: $\mathrm{M}^{+}$at $\mathrm{m} / \mathrm{z} 387$ and $\mathrm{M}^{+2}$ at $\mathrm{m} / \mathrm{z}$ 389; Anal. Calcd for $\mathrm{C}_{22} \mathrm{H}_{14} \mathrm{ClN}_{3} \mathrm{~S}$ : C 68.12, $\mathrm{H}$ 3.64, $\mathrm{N}$ 10.83. Found: $\mathrm{C} 67.96$, H 3.51, N 10.77\%.

Preparation of 8-amino-3-phenyl-1-thioxo-6-p-tolyl -1,2-dihydro-isoquinoline-7-carbonitrile (17b):

The title compound was prepared by the method described above using 2-(4-methylbenzylidene)malononitrile (14b) $(1.68 \mathrm{~g}, 10 \mathrm{mmol})$. The product obtained in yield $(2.88 \mathrm{~g}, 78.37 \%)$ was purified by recrystallisation from ethanol as red crystals, m.p. $172^{\circ} \mathrm{C}-174^{\circ} \mathrm{C}$; IR: $v_{\max }$ at 3342, 3324, $3207\left(\mathrm{NH}_{2}, \mathrm{NH}\right)$ and $2208 \mathrm{~cm}^{-1}(\mathrm{C} \equiv \mathrm{N})$; Anal. Calcd for $\mathrm{C}_{23} \mathrm{H}_{17} \mathrm{~N}_{3} \mathrm{~S}$ : C 75.18, H 4.66, N 11.43. Found: C 75.01, H 4.53, N 11.29\%.

Preparation of 8-amino-6-(4-methoxyphenyl)-3-phenyl-1-thioxo-1,2-dihydro-isoquinoline-7-carbonitrile (17c):

The title compound was prepared by the method described above using 2-(4-methoxybenzylidene)malononitrile (14c) (1.84 g, $10 \mathrm{mmol})$. The product obtained in yield $(2.78 \mathrm{~g}, 72.49 \%)$ was purified by recrystallisation from ethanol as red crystals, m.p. $175^{\circ} \mathrm{C}-177^{\circ} \mathrm{C}$; IR: $v_{\max }$ at 3348, 3329, $3215\left(\mathrm{NH}_{2}, \mathrm{NH}\right)$ and $2206 \mathrm{~cm}^{-1}(\mathrm{C} \equiv \mathrm{N})$; Anal. Calcd for $\mathrm{C}_{23} \mathrm{H}_{17} \mathrm{~N}_{3} \mathrm{OS}$ : C 72.04, H 4.47, N 10.96. Found: C 71.88, H 4.34, N 10.81\%.

\section{References}

[1] Sircar, I., Gregor, E.K., Anderson, K.R., Haleen, S.J., Shih, Y.H., Weishaar, R.E., Steffen, R.P., Pugsly, T.A. and Taylor, M.D. (1991) Calcium Channel Blocking and Positive Inotropic Activities of Ethyl 5-Cyano-1,4-Dihydro-6-Methyl-2-[(Phenylsulfonyl)Methyl]-4-Aryl-3-Pyridinecarboxylate and Analogs. Synthesis and Structure-Activity Relationships. Journal of Medicinal Chemistry, 34, 2248. http://dx.doi.org/10.1021/jm00111a047

[2] Shraideh, Z. and Salla, A.K. (1997) Biomedical Letters, 54, 233.

[3] Gilis, P.M., Haemera, A. and Bollaert, W. (1980) European Journal of Medicinal Chemistry, $15,185$.

[4] Bompart, J., Giral, I., Malicone, G. and Puygrenier, M. (1987) Synthesis and Anti-Bacterial Activities of New 4,7-Dihydro 7-Ethyl 4-Oxo (2,3-b)Thieno Pyridine 5-Carboxylic Acids. European Journal of Medicinal Chemistry, 22, 139145. http://dx.doi.org/10.1016/0223-5234(87)90009-2

[5] Abdel-Rahman, A.E., Bakhite, E.A. and Al-Taifi, E.A. (2002) Journal of the Chinese Chemical Society, 49, 223.

[6] Attaby, F.A., Elneairy, M.A.A. and Elsayed, M.S. (1999) Synthesis and Antimicrobial Evaluation of Several New Pyridine, Thienopyridine and Pyridothienopyrazole Derivatives. Phosphorus, Slfur and Silicon, 149, 49-64. http://dx.doi.org/10.1080/10426509908037022

[7] Eldin, S.M. (1999) Zeitschrift für Naturforschung, 45b, 674.

[8] Adachi, I. and Hiramatsu, Y. (1991) 4,7-Dihydro-5-Alkoxycarbonyl-6-Methyl-4-(Nitrophenyl)Thieno[2,3-b]Pyridine2-Carboxylic Acids as Intermediates for Calcium Channel Blockers. Chemical Abstracts, 115, 71573.

[9] Hussein, A.M. (1998) Zeitschrift für Naturforschung, 53b, 1.

[10] Hussein, A.M., Shrief, S.M. and Atalla, A.A. (1996) A New Synthesis for 1,2,4-Triazolo[1,5-a]-Pyridines and 1,2,4Triazolo[1,5-a]Isoquinolines. Monatshefte für Chemie, 127, 1153-1160. http://dx.doi.org/10.1007/BF00844690

[11] Gelbard, G., Lin, J. and Roques, N. (1992) Reductions with NADH Models. 3. The High Reactivity of Hantzsch Amides. Journal of Organic Chemistry, 57, 1789-1793. http://dx.doi.org/10.1021/jo00032a035

[12] Vieweg, H., Leistner, S. and Wagner, G. (1986) Pharmazie, 41, 827.

[13] Hussein, A.M. (1997) Studies with Polyfunctionally Substituted Heteroaromatics: A Facile Route for the Synthesis of Polyfunctionally Substituted N-Aminopyridines, 1,2,4-Triazolo[1,5-a]Pyridines and Isoquinolines. Heteroatom Chemistry, 8, 1. http://dx.doi.org/10.1002/(SICI)1098-1071(1997)8:1<1::AID-HC1>3.0.CO;2-J 
Scientific Research Publishing (SCIRP) is one of the largest Open Access journal publishers. It is currently publishing more than 200 open access, online, peer-reviewed journals covering a wide range of academic disciplines. SCIRP serves the worldwide academic communities and contributes to the progress and application of science with its publication.

Other selected journals from SCIRP are listed as below. Submit your manuscript to us via either submit@scirp.org or Online Submission Portal.
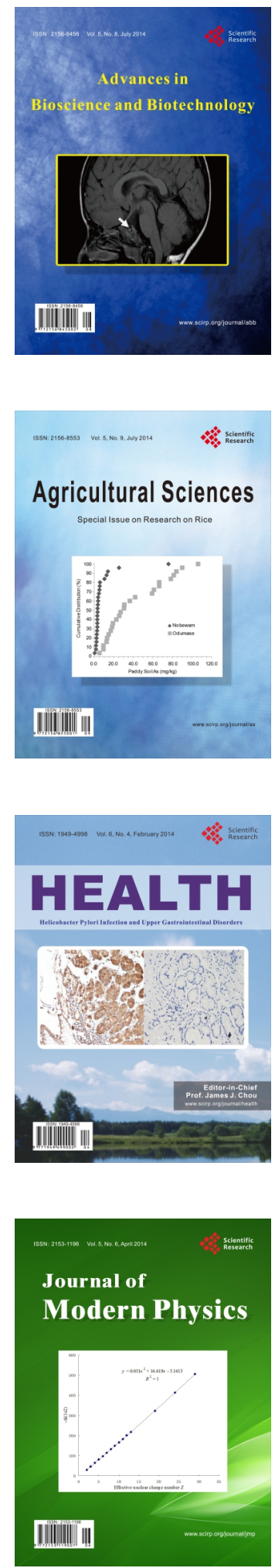
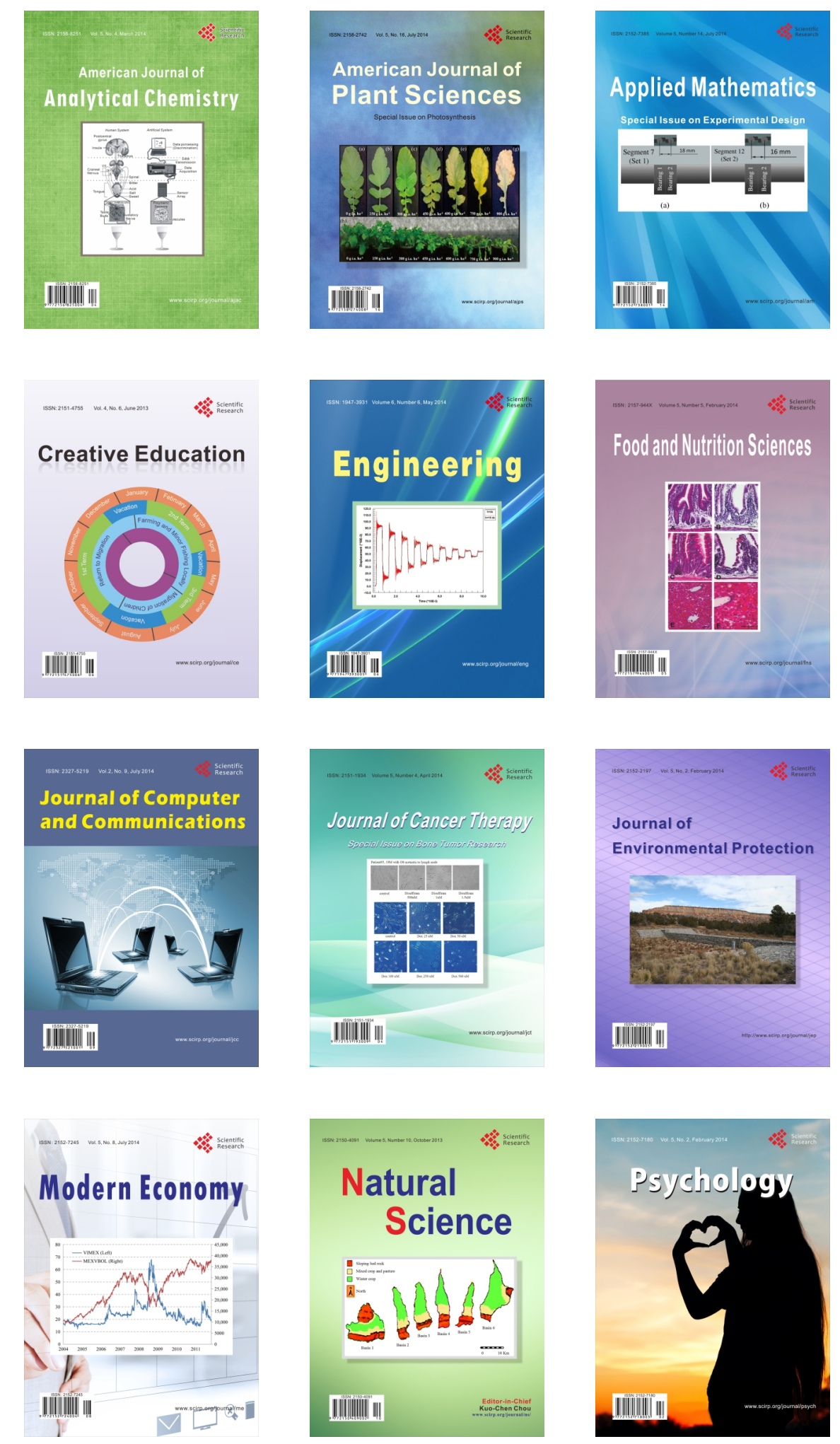